\title{
Home-range and space use by Didelphis albiventris (Lund 1840) (Marsupialia, Didelphidae) in Mutum Island, Paraná river, Brazil
}

\author{
Vítor Quadros Altomare Sanches ${ }^{1,3}$, Mariuciy Menezes de Arruda Gomes ${ }^{1}$, \\ Fernando de Camargo Passos ${ }^{2}$, Gustavo Graciolli ${ }^{1}$ \& Augusto Cesar de Aquino Ribas ${ }^{1}$ \\ ${ }^{1}$ Programa de Pós-graduação em Ecologia e Conservação, \\ Universidade Federal do Mato Grosso do Sul-UFMS, CEP 79070-900, Campo Grande, MS, Brazil \\ http://www.dbi.ufms.br/mstecopan/ \\ ${ }^{2}$ Laboratório de Biodiversidade, Conservação e Ecologia de Animais Silvestres, Departamento de \\ Zoologia, Universidade Federal do Paraná - UFPR, CP 19020, CEP 81531-980, Curitiba, PR, Brazil \\ http://zoo.bio.ufpr.br/ \\ ${ }^{3}$ Corresponding author: Vítor Quadros Altomare Sanches, e-mail: vitorqasanches@hotmail.com
}

SANCHES, V.Q.A., GOMES, M.M.A., PASSOS, F.C., GRACIOLLI, G. \& RIBAS, A.C.A. Home-range and space use by Didelphis albiventris (Lund 1840) (Marsupialia, Didelphidae) in Mutum Island, Paraná river, Brazil. Biota Neotrop.12(4): http://www.biotaneotropica.org.br/v12n4/en/abstract?article+bn00612042012

\begin{abstract}
Home-range is the area used by an animal in its daily activities. Home-range studies provide data on species mating systems and territorial behavior. Our main goal was to estimate the Didelphis albiventris (Lund 1840) home-range in Mutum Island, Paraná River, Brazil. The study was carried out in 2008 from March to October on a 19.20 ha grid. The island is part of the Parana River Islands and Floodlands Federal Environmental Protection Area, with vegetation composed by Alluvial Semideciduous Seasonal Forest in a region of Subtropical Wet climate. The sampling effort was 3,360 traps-night resulting in 152 Didelphis albiventris (Lund 1840) captures. Forty-one Didelphis albiventris (Lund 1840) individuals were captured in 42 capture stations, composed by a trap placed on the floor and another in understory ( $2 \mathrm{~m}$ high). The animals were mostly terrestrial, independently of age or sex. Four females and five males, which were recaptured at least five times, were used to calculate homerange using the minimum convex polygon method. The mean home-range estimate was $2.33 \pm 2.32$ ha, similar to previous estimates provided by other methods, suggesting that our capture grid area, that was larger than usually applied for mark-capture studies for this species, have not underestimated the home-ranges. Evidences of the relation between individual home-range area and body mass were observed. Home-range overlaps occurred between males, females and males with females; the average overlap was $33.74 \%$, which may be related to a promiscuous mating system, and suggests female territoriality.
\end{abstract}

Keywords: Atlantic Forest, capture-recapture, minimum convex polygon, vertical habitat use, white-earedopossum.

SANCHES, V.Q.A., GOMES, M.M.A., PASSOS, F.C., GRACIOLLI, G. \& RIBAS, A.C.A. Área de vida e uso do espaço por Didelphis albiventris (Lund 1840) (Marsupialia, Didelphidae) na ilha Mutum, rio Paraná, Brasil. Biota Neotrop. 12(4): http://www.biotaneotropica.org.br/v12n4/pt/abstract?article+bn00612042012

Resumo: Área de vida é a área usada por um animal em suas atividades diárias. Estudos de área de vida oferecem dados sobre os sistemas reprodutivos e comportamento territorial das espécies. Nosso objetivo foi estimar a área de vida de Didelphis albiventris (Lund 1840) na ilha Mutum, no rio Paraná, Brasil. O estudo foi realizado em 2008 de março a outubro em uma grade de 19,20 ha. Esta ilha é parte da área de proteção de ilhas e várzeas do rio Paraná e sua vegetação é composta por floresta estacional semidecidual aluvial sazonal com clima subtropical úmido. O esforço amostral foi de 3.360 armadilhas-noite resultando em 152 capturas de Didelphis albiventris (Lund 1840). Foram capturados 41 indivíduos nas 42 estações compostas por uma armadilha no solo e a dois metros de altura. A maioria dos animais foi capturada no solo, independente de idade ou sexo. Quatro fêmeas e cinco machos foram recapturados pelo menos cinco vezes e foram usados para calcular a área de vida mediante método de polígono mínimo convexo. A área de vida média estimada foi de 2,33 ha $\pm 2,32$, similar às estimativas previamente descritas por outros métodos, sugerindo que o tamanho da grade de captura, maior que a usualmente empregada em estudos de marcação-recaptura com esta espécie, não subestimou as áreas de vida. Evidências da relação entre a área de vida e massa corporal dos indivíduos foram observadas. Sobreposição das áreas de vida (média $=33,74 \%$ ) ocorreu entre machos, entre fêmeas e de machos com fêmeas, o que pode ser relacionado a um sistema de acasalamento promíscuo e territorialidade de fêmeas.

Palavras-chaves: Mata Atlântica, captura-recaptura, mínimo polígono convexo, uso vertical do hábitat, gambáde-orelha-branca. 


\section{Introduction}

Home-range is the area used by an individual to forage, reproduce, rest and accomplish all its daily activities (Burt 1943). Home-range varies with animal size and food habit: larger animals usually need more food and therefore a larger home-range; specialist animals usually have larger home-ranges than generalists due to difficulties to find food (Krebs \& Davies 1996).

Differences between home-ranges of males and females are common, for example, females defend fixed territories, while males searching for females do not defend their territories, which results in females with a higher territoriality than males (Wolf 1993, Loretto \& Vieira 2005). This pattern may be explained by increased energy requirements of pregnant and lactating females compared to males, usually observed in breeding seasons (Gentile et al. 1997, Cáceres 2003, Loretto \& Vieira 2005).

The home-range overlap provides information on the mating system: the overlap of many females and one male can express a promiscuous behavior; fidelity will be seen as an overlap of only one couple (Madison 1980); and evidences of territorial behavior can be seen in no overlap between individuals in almost all cases (Cáceres 2003). The kangaroo rat, Dipodomys ingens (Merriam 1904), only overlaps their home-range intersexually, males with females, showing a sex-biased exclusivity of the home-range (Braun 1985).

Two theories try to explain the occurrence of home-ranges overlap by territorial behavior of small mammal females. The first theory relies on the resources defense, which involves the defense of territories with good quality of limiting resources against all individuals that use the same resources. The second theory is more empirically supported. It is called "pup-defense" and relies on the defense of offspring from unrelated males and females (Wolf 1993).

Female marsupials usually overlap their home-ranges. However during the reproductive season they increase territoriality (Pires \& Fernadez 1999, Cárceres \& Monteiro-Filho 2001, Cáceres 2003, Martins 2004). Males usually have larger home-range than females (Gentile et al. 1997, Cáceres 2003, Loretto \& Vieira 2005). Older, larger and heavier individuals tend to use larger areas than smaller and younger animals (Cáceres 2003). There are also temporal variations in the home-range of marsupials, which in general have larger areas during the breeding season (Gentile et al. 1997, Cáceres 2003, Loretto \& Vieira 2005). For the Didelphis genus this home-range can still be divided by upper and lower strata, with upper strata mainly operated by younger and smaller individuals as observed for Didelphis aurita (Wied-Neuwied 1826) (Pires \& Fernandez 1999). Young individuals of this species seem to have a more arboreal life than adults (Cunha \& Vieira 2005).

Studies on home-range and use of space with the catch grid technique include rodents, such as Akodon cursor (Winge 1887) (Gentile et al. 1997), Peromyscus boylii (Baird 1955) and Peromyscus truei (Shufedlt 1885) (Ribble et al. 2002) and marsupials, such as Philander frenata (Olfers 1818) (Gentile et al. 1997), Gracilinanus microtarsus (Wagner 1842) (Martins 2004), Didelphis aurita (Wied-Neuwied 1826) (Cáceres 2003) and Micoureus demerarae (Thomas 1905) (Moraes-Junior \& Chiarello 2005). Studies with the white-eared opossum Didelphis albiventris (Lund 1840) became increasingly common, due to the few logistical constraints: high abundance, wide distribution, high synanthropism and preference for living in fragments and disturbed areas (Cáceres \& Monteiro-Filho 2006).

D. albiventris (Lund 1840) is the largest Brazilian didelphid, and is considered scansorial (Vieira 2006), solitary, generalist and omnivorous (Cabrera \& Yepes 1960). Variations in home-range size according to age, sex, weight, distribution of resources, among other factors have been described (Cáceres 2003, Cáceres \& MonteiroFilho 2006). With increasing deforestation, D. albiventris (Lund 1840) has been approaching urban areas and acquired synanthropic habits. They often end up being caught in homes and households, sometimes attacking people which impose a danger for both rural and urban houses acting like diseases carrier, being a rabies or leishmania reservoir, for example (Almeida et al. 2008, Cáceres et al. 2008). Moreover, these animals are well adapted to habitat fragmentation (Fonseca \& Robinson 1990, Cáceres 2000, Almeida et al. 2008, Cáceres et al. 2008), which requires management information about landscapes and biomes that have become fragmented (Lambert et al. 2006).

Here we aim to estimate the average home-range of $D$. albiventris (Lund 1840) in Mutum Island to (1) verify whether are differences in the home-range size between males and females, (2) evaluate the influence of the individual body mass in the size of their home-range, (3) describe the home-range overlapping and (4) analyze whether there are differences in the frequency of use of ground or understory by the opossums.

\section{Materials and Methods}

\section{Study area}

Samples were collected on "Mutum Island" $\left(22^{\circ} 45^{\prime} 58^{\prime} \mathrm{S}\right.$ and $53^{\circ} 19^{\prime} 13$ " W) which is part of the High Paraná river fluvial archipelago, located on Paraná river, Taquarussu city in the state of Mato Grosso do Sul, border with state of Paraná (Miranda et al. 2007). The island (1050 ha) is part of the Paraná River Islands and Floodlands Federal Environmental Protection Area (Mikich \& Bernils 2004). The area is located in a region where the mean annual temperature is $22{ }^{\circ} \mathrm{C}$, the altitude is 250 meters and the climate is humid subtropical climate, Cfa h, according to Köeppen (Maack 1968).

The vegetation is semideciduous alluvial forest composed of primary forest with 30 meters height dossel, riparian, secondary forest (in various stages of succession) and disturbed habitats (Campos \& Souza 1997). The island's vegetation complexity was well sampled, since the capture grid crossed the island covering areas with a characteristic vegetation of secondary succession and disturbed areas with several guava trees (Psidium sp.), embaúba trees (Cecropia sp.), Brachiaria sp., bamboo plantation (Bambuseae), tucum palms (Bactris sp.) and flooded areas with macrophytes and ingá trees (Inga sp.).

\section{Capture procedures}

The survey was carried out from March to October 2008, with five nights per month. Live traps of galvanized wire measuring $45 \times 16 \times 16 \mathrm{~cm}$ and with trigger hook were used. The baits used were a mix of a banana slice with sardine oil, cod liver oil and peanut butter.

The grid consisted of seven parallel lines with six traps each. These lines transversally crossed the island from north to south. Lines were 80 meters apart from each other, as well as the trap stations on each line resulting in a $7 \times 6$ grid with distance between traps and lines determined with tape measures and directions of each line with a compass, resulting in a grid total area of approximately 19.20 ha.

Each capture site was composed of two traps, one on the ground and another about two meters high on the nearest tree to the point determined, totalizing a grid of 84 traps. The traps were set on the trees using a 'L' shaped metal: the shorter part of the " $L$ " bracket was attached to the tree, while the longer part was attached to the trap. Thus the trap is perpendicular to the tree with its entrance facing towards the trunk (Monteiro-Filho \& Graipel 2006). 
All individuals of $D$. albiventris captured for the first time were marked, weighted, measured, sexed and had their age estimated. The age of the animals was estimated from the number of hatched molars: the animal withtwo molars hatched was classified as young, three molars subadult and four molars an adult (Tyndale-Biscoe \& Mackenzie 1976, Cáceres \& Monteiro-Filho 1999, Graipel et al. 2006). Capture station and where the trap was placed (floor or understory) were also recorded. The specimens were marked by punching the ears with leather awl. This method allows tracking up to 99 animals in up to two holes per ear. The right ear composes the units while the left ear comprises the dozens. Recaptured animals in the same field campaign were immediately released, while for individuals recaptured in different campaigns the entire procedure was performed, to evaluate changes in size and body mass.

\section{Data analysis}

To estimate home-range we used the minimum convex polygon method (MCP) (Jennrich \& Tuner 1969). Since home-range size is related to the number of recaptures (Batzli \& Henttonnen 1993), we used the number of recaptures as a covariate in the analysis. We calculated proportional overlap by measuring the area in each home-range (the target animal) that was shared by other animal's home-range of the same sex (intrasexual overlap) or other animal's home-range of the opposite sex (intersexual overlap), and dividing by the area of the target animal home-range. We assume, as suggested by Batzli \& Henttonnen (1993), that home-range overlap significantly lower than random placement indicates that individuals are avoiding one another and it is considered evidence of territorial behavior. We used chi-square with first captures of $D$. albiventris (Lund 1840) individuals to verify the differences in the use of space between males and females and young, subadults and adults. All analyses were carried out using the language $\mathrm{R}$ (R Development... 2011) with package adehabitatHR (Calenge 2006).

To assess which factors determine the home-range sizes we applied an analysis of covariance (ancova) using sex (categorical variable), body mass and number of captures as predictor variables. Akaike's Information Criterion (AIC) was used to select the most parsimonious model (see Burnham \& Anderson 2002). This criterion may be useful to identify a single model from a particular hypothesis or infer the best solution from a set of competitive models (Johnson \& Omland 2004).

\section{Results}

The total effort of 3.360 traps-night resulted in 849 small mammals captures, with 146 capture events of 41 individuals of $D$. albiventris (Lund 1840): 17 females (five young, eight subadult, and four adults) and 24 males (six young, four subadults and 14 adults). Only nine individuals ( 4 females and 5 males) were recaptured at least five times and were used to estimate home-range. The average MCP estimated for all individuals was $2.33 \mathrm{ha} \pm 2.32 \mathrm{SD}$. For males, the average home-range was $3.20 \pm 2.78$ ha, while for females the average was $1.47 \pm 1.59$ ha. The largest home-range estimated was 7.04 ha for a male; the smaller was 0.64 ha for a female (Table 1). The most parsimonious model to predict home-range (Table 2) was dependent of individual body mass and the number of captures (Figure 1).
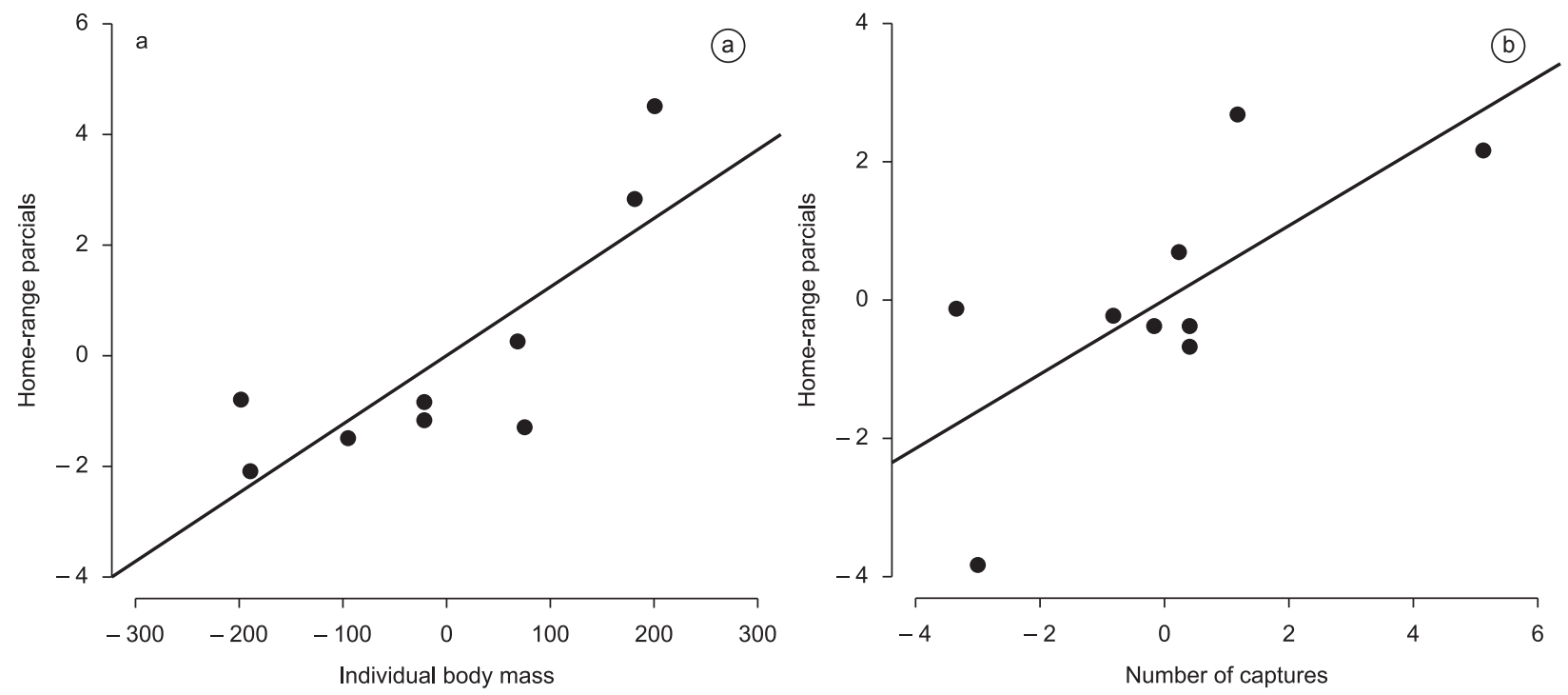

Figure 1. Partial regressions of Home-range with Individuals body mass (a) and Number of captures (b) obtained by a multiple regression model.

Table 1. Sex, mean mass (g), head lenght (mm), home-range (ha) and number of captures per individual.

\begin{tabular}{lccccc}
\hline \multicolumn{1}{c}{ Individual } & Mass & Head heights measure & Home-range & Number of captures & Age \\
\hline Female 01 & 700.7 & 85.2 & 4.16 & 15 & 07 \\
Female 02 & 634.3 & 91.1 & 1.28 & 10 & Adult \\
Female 03 & 517.0 & 88.8 & 0.64 & 10 & Adult \\
Female 04 & 661.0 & 88.3 & 1.28 & 15 & Adult \\
Male 01 & 736.0 & 90.7 & 0.32 & 08 & Adult \\
Male 02 & 1000.0 & 96.7 & 5.12 & 10 & Adult \\
Male 03 & 900.0 & 95.2 & 1.60 & 09 & Adult \\
Male 04 & 1000.0 & 101.5 & 7.04 & 05 & Adult \\
Male 05 & 958.0 & 102.3 & 1.92 & & Adult \\
\hline
\end{tabular}


There were intra and intersex home-range overlap. Only one female did not overlap its home-range with any other female and three males. Males overlapped their home range between males and females (Figure 2). The average overlap percentage was $33.74 \%$ for all individuals, $33.32 \%$ among females and $42.29 \%$ among males. From the 72 possible overlaps, 17 were observed among females and 29 among males, with no significant difference $\left(X^{2}=5, p=0.09\right.$ and $\mathrm{GL}=1$ ).

Considering the first captures of the $41 D$. albiventris (Lund 1840) individuals obtained, 27 were on the floor and 14 occurred in the understory, which suggests that the ground was used more frequently $\left(\mathrm{X}^{2}=4.12, \mathrm{p}=0.04\right.$ and $\left.\mathrm{GL}=1\right)$. Young, subadult and adult specimens showed the same frequency of the use of strata. Eight of the ten young specimens were captured on the ground and two in the understory; nine of 13 subadults were captured on the floor and four in the understory; and 10 of 18 adults were captured in the ground and eight in the understory $\left(\mathrm{X}^{2}=1.86, \mathrm{p}=0.39\right.$ and $\left.\mathrm{GL}=2\right)$. Moreover, females and males did not differ in strata use. Ten females were captured on the ground and seven in the understory $(n=17)$; 17 males were captured on the ground and seven in the understory $(\mathrm{n}=24)\left(\mathrm{X}^{2}=0.63, \mathrm{p}=0.43\right.$ and $\left.\mathrm{GL}=1\right)$.

Table 2. Initial and most parsimonious regression model (selected by AIC), to predict home-range.

\begin{tabular}{|c|c|c|c|c|}
\hline $\mathbf{A}$ & Estimate & $\begin{array}{c}\text { Standard } \\
\text { error }\end{array}$ & $t$-value & $P$-value \\
\hline Intercept & -13.39 & 4.8 & -2.79 & 0.03 \\
\hline Sex male & -1.22 & 1.73 & -0.71 & 0.51 \\
\hline Mass & 0.01 & 0.01 & 2.67 & 0.04 \\
\hline Number of captures & 0.52 & 0.22 & 2.27 & 0.07 \\
\hline B & Estimate & $\begin{array}{c}\text { Standard } \\
\text { error }\end{array}$ & $t$-value & $P$-value \\
\hline Intercept & -11.94 & 4.16 & -2.87 & 0.03 \\
\hline Mass & 0.01 & 0.01 & 3.35 & 0.02 \\
\hline Number of captures & 0.54 & 0.22 & 2.48 & 0.04 \\
\hline
\end{tabular}

Initial regression model (A): $\mathrm{R} 2=0.70, \mathrm{~F}=4.01$ on 3 and $5 \mathrm{DF}, \mathrm{p}=0.08$, $\mathrm{AIC}=10.95$. Most parsimonious regression model $(\mathrm{B}): \mathrm{R} 2=0.67, \mathrm{~F}=2.77$ on 2 and $6 \mathrm{DF}, \mathrm{p}=0.03, \mathrm{AIC}=9.81$.

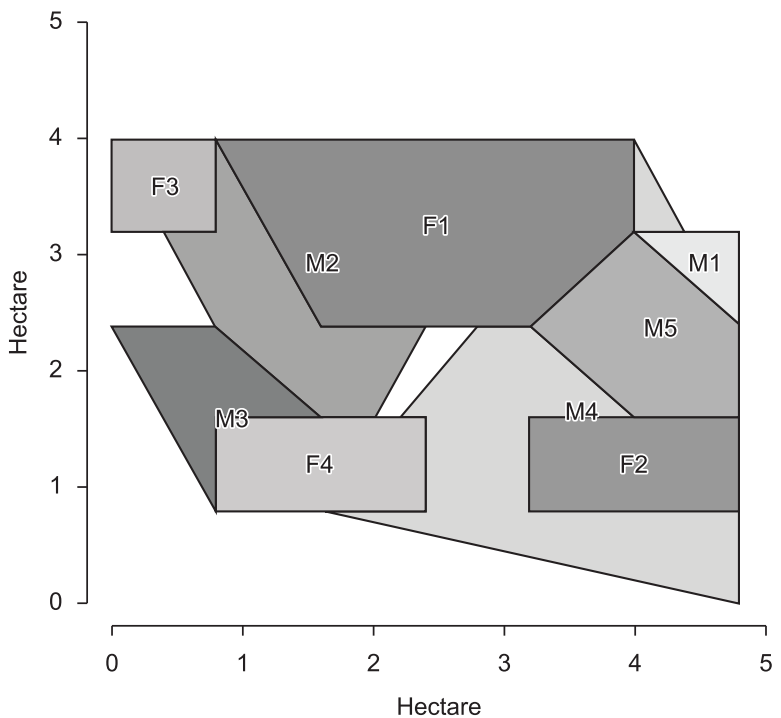

Figure 2. Spatial plot of all home-range estimates (ha). F means Female and M means Male, the numbers follow the order presented in Table 1.

\section{Discussion}

This is the first effort in studying home-range of $D$. albiventris (Lund 1840) in an island. In general, populations confined to islands develop the so-called insular syndrome (Adler \& Levins 1994), which predicts that populations with this syndrome are usually at higher densities and therefore end up relaxing their intraspecific interactions, reducing the home-range area and increasing the overlap (Adler \& Levins 1994, Goltsman et al. 2005). The mean home-range estimated for this population is considerably higher than the previously observed in an urban fragment of araucaria forest in Curitiba city, Paraná State $(0.68 \pm 0.58$ ha with $0.66 \pm 0.44$ ha for females and $0.69 \pm 0,80$ ha for males on average; first author unpublished data).

The capture grid used in this study (19.2 ha), as far as we are concerned, is the largest used in studies of home range for Brazilian didelphids (maximum of 5 ha - Cáceres 2003; minimum of 0.36 ha - Martins 2004). The capture success of 5\% for D. albiventris (Lund 1840) is consistent with other studies: approximately $6 \%$ in a semideciduous forest of Minas Gerais State (Almeida et al. 2008) and $5 \%$ in an urban fragment of araucaria forest in Curitiba city, Paraná State (Cáceres \& Monteiro-Filho 1999).

The difference in the size of capture grids used (19.20 ha versus $3.6 \mathrm{ha}$ ), the number of captures (Figure 1b) and the distance between traps $(80 \mathrm{~m}$ versus $30 \mathrm{~m})$ may lead to underestimated home-ranges (Martins 2004). However, our estimates might not be underestimated when we compare our study to others similar but using other techniques. In the only study conducted using radio-telemetry with D. albiventris (Lund 1840), home range area was 3.83 and 6.83 ha for two adult males (Aléssio 2004), similar to values we obtained, showing that the catch grid size used in our study may be adequate for studies of home-range for didelphids. Studies on D. aurita (WiedNeuwied 1826), another species very similar in morphology to $D$. alviventris, have estimated home-ranges varying from 0.20 to 3.0 ha (Cáceres \& Monteiro-Filho 2001) and from 0.58 to 2.73 ha (Cáceres 2003). The minimum value we describe for $D$. albiventris (Lund 1840) is approximately the maximum value found in those studies, which may be an influence of the grid size ( $4.3 \mathrm{ha})$ and distance between traps (38 m, Cáceres 2003).

Our findings also suggests that body mass is a significant factor determining the size of the home-range for many didelphids (Vieira \& Cunha 2008), which is already known for mammals as a primary determinant of home-range for (Ottaviani et al. 2006). The significant relation of home-range size with the body mass of animals is widely reported. Larger animals have larger home-ranges (Mcnab 1963, Krebs \& Davies 1996, Cáceres 2003, Martins 2004, Ottaviani et al. 2006). Other Brazilian marsupials also responded directly to this relationship, for example, G. microtarsus (Wagner 1842) (Martins 2004) and D. aurita (Wied-Neuwied 1826) (Cáceres 2003), both species considered omnivorous (Santori \& Moraes 2006).

There was no significant difference in the size of the home-ranges for males and females. These results are similar to those estimated by spool-and-line techniques (Almeida et al. 2008), but differ from the observed for other Brazilian marsupials, for example $D$. aurita (Wied-Neuwied 1826) (Cáceres 2003, Loretto \& Vieira 2005), G. microtarsus (Wagner 1842) (Martins 2004), M. demerarae (Thomas 1905) (Moraes-Junior \& Chiarello 2005). The similarity in homerange sizes for males and females of the white-eared opossums may be explained by an apparent lack of sexual dimorphism regarding the mass of males and females of D. albiventris (Lund 1840) (Cáceres \& Monteiro-Filho 1999).

Overlapping home-range areas among males, between females and between males and females show that D. albiventris (Lund 1840) follows a pattern already found for Brazilians didelphids. 
This same pattern has been described for D. aurita (Wied-Neuwied 1826) (Cáceres 2003), M. demerarae (Thomas 1905) (Pires \& Fernandez 1999, Moraes-Junior \& Chiarello 2005), G. microtarsus (Wagner 1842) (Martins 2004), P. frenata (Olfers 1818) (Gentile et al. 1997), and is taken as evidence of a promiscuous mating system (Ostfeld 1990, Krebs \& Davies 1996, Gentile et al. 1997). The high overlapping home-range suggests an absence of territorial behavior (Sandell 1989), which has been shown for other Brazilians didelphids as $P$. frenata (Olfers 1818) (Gentile et al. 1997). However, D. aurita demonstrated evidence of territoriality only during the breeding season (Cáceres 2003). Territoriality in Brazilian marsupials appears to be closely linked to reproduction (Pires \& Fernandez 1999, Cáceres 2003). Females showed less overlap than males indicating that females tend to be more territorial.

D. albiventris (Lund 1840) seems to prefer the soil to understory, independent of sex and age, suggesting that these animals forage and find shelter mainly in the soil, similar to D. aurita (Wied-Neuwied 1826) which also shows more terrestrial than arboreal tendency in areas of semideciduous Atlantic forest (Vieira 2006), the same vegetation in Mutum Island. Young D. aurita (Wied-Neuwied 1826) seem to use more the understory than subadults and adults (Cunha \& Vieira 2005), since their feet and claws are relatively larger than those of adult animals and their mass and body size are smaller (Vieira 1997).

Home-range and use of space studies based on catch grids require large areas, are cheaper and allow a perception of the population as a whole, but result in fewer points when compared to radio-telemetry, which can reduce the power of statistical tests and demands more sampling effort (Jones \& Sherman 1983, Gurnell \& Gipps 1989). Multiple captures grids or a combination with radio-telemetry is suggested to reduce the possibility of underestimating the homerange (Lira \& Fernandez 2009) and use of published data as priors for a Bayesian approach.

\section{Acknowledgements}

We are grateful to the Conselho Nacional de Desenvolvimento Científico e Tecnológico (CNPq) for support through Research Grant (471699/2007-1), to Coordenação de Aperfeiçoamento de Pessoal de Nivel Superior (CAPES), to the partners and employees of the Rio Baia Fishing Club, to the UFMS Graduation Program in Conservation Ecology, especially to Silvia Roberta Cieslak, who translated the manuscript and two anonymous referees that greatly improved the quality of the manuscript.

\section{References}

ADLER, G.H. \& LEVINS, R. 1994. The island syndrome in rodent populations. Q. Rev. Biol. 69:473-490.

ALÉSSIO, F.M. 2004. Comportamento de Didelphis albiventris em um remanescente de mata Atlântica no Nordeste do Brasil. Dissertação de Mestrado, Universidade Federal de Pernambuco, Recife, 39p.

ALMEIDA, A.J., TORQUETTI, C.G. \& TALAMONI, S.A. 2008. Use of space by Neotropical marsupial Didelphis albiventris (Didelphimorphia) in an urban forest fragment. Rev. Bras. Zool. 25:214-219. http://dx.doi. org/10.1590/S0101-81752008000200008

BATZLI, G.O. \& HENTTONEN, H. 1993. Home range and social organization of the singing vole (Microtus miurus). J. Mammal. 74:868-878. http:// dx.doi.org/10.2307/1382425

BRAUN, S.E. 1985. Home range and activity patterns of the giant kangaroo Rat, Dipodomys ingens. J. Mammal. 66:1-12. http://dx.doi. org/10.2307/1380950

BURNHAM, K.P. \& ANDERSON, D.R. 2002. Model selection and multimodel inference. Springer, New York.
BURT, W.H. 1943. Territoriality and home range as applied to mammals. J. Mammal. 24:346-352. http://dx.doi.org/10.2307/1374834

CABRERA, A. \& YEPES, J. 1960. Mamíferos Sudamericanos. Vida, costumes y descripción. Ediar, Buenos Aires.

CÁCERES, N.C. 2000. Population ecology and reproduction of the whiteeared opossum Didelphis albiventris (Mammalia, Marsupialia) in an urban environment of Brazil. Cienc. Cult. 52(3):171-174.

CÁCERES, N.C. 2003. Use of the space by the opossum Didelphis aurita Wied-Newied (Mammalia, Marsupialia) in a mixed forest fragment of southern Brazil. Rev. Bras. Zool. 20(2):315-322. http://dx.doi. org/10.1590/S0101-81752003000200023

CÁCERES, N.C. \& MONTEIRO-FILHO, E.L.A. 1999. Tamanho corporal em populações naturais de Didelphis (Mammalia: Marsupialia) do sul do Brasil. Rev. Bras. Biol. 59(3):461-469. http://dx.doi.org/10.1590/ S0034-71081999000300011

CÁCERES, N.C. \& MONTEIRO-FILHO, E.L.A. 2006. Uso do Espaço por Marsupiais: Fatores Influentes, Comportamento e Heterogeneidade Espacial. In Os marsupiais do Brasil: biologia, ecologia e evolução (N.C. Cáceres \& E.L.A. Monteiro-Filho, eds.). Mato Grosso do Sul Federal University Press, Campo Grande, p.203-215.

CÁCERES, N.C. \& MONTEIRO-FILHO, E.L.A. 2001. Food habits, home and activity of the common opossum (Didelphis marsupialis) in a forest fragment of southern Brazil. Stud. Neotrop. Fauna E. 36(2):85-92. http:// dx.doi.org/10.1076/snfe.36.2.85.2138

CÁCERES, N.C., CASELLA, J., VARGAS, C.F., PRATES, L.Z., TOMBINI, A.A.M. \& GOULART, C.S. 2008. Distribuição geográfica de pequenos mamíferos não voadores nas bacias dos rios Araguaia e Paraná, região centro-sul do Brasil. Iheringia Sér. Zool. 98(2):173-180.

CALENGE, C. 2006. The package adehabitat for the R software: a tool for the analysis of space and habitat use by animals. Ecol. Model. 197:516-519. http://dx.doi.org/10.1016/j.ecolmodel.2006.03.017

CAMPOS, J.B. \& SOUZA, M.C. 1997. Vegetação. In A Planície de Inundação do Alto Rio Paraná: Aspectos físicos, biológicos e socioeconômicos (Vazzoler AEA, Agostinho AA \& Hahn NS, eds.). Maringá State University, Maringá. p.331-342.

CUNHA, A.A. \& VIEIRA, M.V. 2005. Age, season, and arboreal movements of the opossum Didelphis aurita in an Atlantic rain forest of Brazil. Acta Theriol. 50:551-560. http://dx.doi.org/10.1007/BF03192648

FONSECA, G.A.B. \& ROBINSON, J.G. 1990. Forest size and structure - competitive and predatory effects on small mammal communities. Biol. Conserv. 53(4):265-294. http://dx.doi. org/10.1016/0006-3207(90)90097-9

GENTILE, R., D'AANDREA, P.S. \& CERQUEIRA, R. 1997. Home ranges of Philander frenata and Akodon cursor in a Brazilian Restinga (Coastal Shrubland). Mastozool. Neotrop. 4:105-112.

GOLTSMAN, M., KRUCHENKOVA, E.P., SERGEEV, S., VOLODIN, I. \& MACDONALD, D.W. 2005. Island syndrome in a population of Arctic foxes (Alopex lagopus) from Mednyi Island. J. Zool. 267:405-418. http:// dx.doi.org/10.1017/S0952836905007557

GRAIPEL, M.E., CHEREM, J.J., MONTEIRO-FILHO, E.L.A. \& GLOCK, L. 2006. Dinâmica populacional de marsupiais e roedores no Parque Municipal da Lagoa do Peri, Ilha de Santa Catarina, sul do Brasil. Mastozool. Neotrop. 13(1):31-49.

GURNELL, J. \& GIPPS, J.H.W. 1989. Inter-trap movement and estimating rodent densities. J. Zool. 217:241-254. http://dx.doi. org/10.1111/j.1469-7998.1989.tb02485.x

JENNRICH, R.I. \& TURNER, F.B. 1969. Measurement of non-circular home range. J. Theor. Biol. 22(2):227-237. http://dx.doi.org/10.1016/00225193(69)90002-2

JOHNSON, J.B. \& OMLAND, K.S. 2004. Model selection in ecology and evolution. Trends. Ecol. Evol. 19(2):101-108. PMid:16701236. http:// dx.doi.org/10.1016/j.tree.2003.10.013

JONES, E.N. \& SHERMAN, L.J. 1983. A comparison of meadow vole home ranges derived from grid trapping and radiotelemetry. J. Wildlife Manage. 47:558-561. http://dx.doi.org/10.2307/3808537 
KREBS, J.R. \& DAVIES, N.B. 1996. Introdução à Ecologia Comportamental. Atheneu Press, São Paulo.

LAMBERT, T.D., MALCOLM, J.R. \& ZIMMERMAN, B.L. 2006. Amazonian small mammal abundances in relation to habitat structure and resource abundance. J. Mammal. 87(4):766-776. http://dx.doi. org/10.1644/05-MAMM-A-261R1.1

LIRA, P.K. \& FERNANDEZ, F.A.S. 2009. A comparison of trapping and radiotelemetry based estimates of home range of the neotropical opossum Philander frenatus. Mammal. Biol. 74:1-8. http://dx.doi.org/10.1016/j. mambio.2008.05.002

LORETTO, D. \& VIEIRA, M.V. 2005. The effects of reproductive and climatic seasons on moviments in the black-eared opossum (Didelphis aurita Wied-Neuwied, 1826). J. Mammal. 86(2):287-293. http://dx.doi. org/10.1644/BEH-117.1

MAACK, R. 1968. Geografia física do Estado do Paraná. Max Roesner Press, Curitiba, Paraná.

MADISON, D.M. 1980. Space use and social structure in meadow voles, Microtus pennsylvanicus. Behav. Ecol. Sociobiol. 7:65-71. http://dx.doi. org/10.1007/BF00302520

MARTINS, E.G. 2004. Ecologia Populacional e Área de Vida da Cuíca Gracilinanus microtarsus (Marsupialia: Didelphidae) em um Cerradão de Américo Brasiliense, São Paulo. Dissertação de mestrado, Universidade Estadual de Campinas, Campinas.

McNAB, B.K. 1963. Bioenergetics and the determination of home range size. Am. Nat. 97:133-140. http://dx.doi.org/10.1086/282264

MIKICH, S.B. \& BÉRNILS, R.S. 2004. Livro vermelho da fauna ameaçada no Estado do Paraná. Paraná State Government, Environment Boureau.

MIRANDA, J.M.D., PULCHÉRIOLEITE, A., BERNARDI, I.P. \& PASSOS, F.C. 2007. Primeiro registro de Myotis albescens (Geoffroy E 1806) (Chiroptera, Vespertilionidae) para o Estado do Paraná, Brasil. Bioto Neotrop. 7(1):13-15.

MONTEIRO-FILHO, E.L.A. \& GRAIPEL, M.E. 2006 Captura e Marcação In Os marsupiais do Brasil: biologia, ecologia e evolução (N.C. Cáceres \& E.L.A. Monteiro-Filho, eds.). Mato Grosso do Sul Federal University press, Campo Grande, p.17-27.

MORAES-JÚNIOR, E.A. \& CHIARELLO, A.G. 2005. A radio tracking study of home range and movements of the marsupial Micoureus demerarae (Thomas) (Mammalia, Didelphidae) in the Atlantic forest of southeastern Brazil. Rev Bras Zool. 22(1):85-91. http://dx.doi.org/10.1590/ S0101-81752005000100011

OSTFELD, R.S. 1990. The ecology of territoriality in small mammals. Ecol. Evol. 5:411-415. http://dx.doi.org/10.1016/0169-5347(90)90026-A
OTTAVIANI, D., CAIRNS, S.C., OLIVERIO, M. \& BOITANI, L. 2006. Body mass as a predictive variable of home-range size among italian mammals and birds. J. Zool. 269:317-330. http://dx.doi.org/10.1111/ j.1469-7998.2006.00060.x

PIRES, A.S. \& FERNANDEZ, F.A.S. 1999. Use of space by the marsupial Micoureus demerarae in small Atlantic Forest fragments in southeastern Brazil. J. Trop. Ecol. 15:279-290. http://dx.doi.org/10.1017/ S0266467499000814

R DEVELOPMENT CORE TEAM 2011. R: A language and environment for statistical computing. R Foundation for Statistical Computing, Vienna, Austria. http://www.R-project.org/

RIBBLE, D.O., WURTZ, A.E., McCONNEL, E.K., BUEGGE, J.J. \& WELCH JUNIOR, K.C. 2002. A comparison of home ranges of two species of Peromyscus using trapping and radiotelemetry data. J. Mammal. 83:260266. http://dx.doi.org/10.1644/1545-1542(2002)083<0260:ACOHRO > 2.0.CO;2

SANDELL, M. 1989. The mating tactics and spacing patterns of solitary carnivores. In Canivore Bahavior, Ecology and Evolution (J.L. Gittleman, ed.). Cornell University, Ithaca, p.164-182. http://dx.doi.org/10.1007/9781-4613-0855-3_7

SANTORI, R.T. \& MORAES, D.A. 2006. Alimentação, nutrição e adaptações alimentares de marsupiais brasileiros. In Os marsupiais do Brasil: biologia, ecologia e evolução (N.C. Cáceres \& E.L.A. Monteiro-Filho, eds.). Mato Grosso do Sul Federal University Press, Campo Grande, p.241-254.

TYNDALE-BISCOE, C.H. \& MACKENZIE, R.B. 1976. Reproduction in Didelphis marsupialis and D. albiventris in Colombia. J. Mammal. 57(2):249-265. http://dx.doi.org/10.2307/1379686

VIEIRA, M.V. 1997. Body size and form of two neotropical marsupials (Didelphimorphia, Didelphidae). Mammalia 61(2):45-254. http://dx.doi. org/10.1515/mamm.1997.61.2.245

VIEIRA, M.V. 2006. Locomoção, morfologia e uso do habitat em marsupiais didelfídeos: em busca de um modelo ecomorfológico. In Os marsupiais do Brasil: biologia, ecologia e evolução (N.C. Cáceres \& E.L.A. MonteiroFilho, eds.). Mato Grosso do Sul Federal University Press, Campo Grande, p.299-301.

VIEIRA, M.V. \& CUNHA, A.A. 2008. Scaling body mass and use of space in three species of marsupials in the Atlantic Forest of Brazil. Austral. Ecol. 33(7):872-879. http://dx.doi.org/10.1111/j.1442-9993.2008.01858.x

WOLF, J.O. 1993. Why are female small mammals territorial? Oikos. 68:364370. http://dx.doi.org/10.2307/3544853 